\title{
Inheritance of Fruit, Foliar, and Plant Habit Attributes in Capsicum
}

\author{
John R. Stommel ${ }^{1}$ \\ U.S. Department of Agricultural, Agricultural Research Service, Beltsville Agricultural Research \\ Center, Genetic Improvement of Fruits and Vegetables Laboratory, Plant Sciences Institute, \\ Building 010A, BARC-West, 10300 Baltimore Avenue, Beltsville, MD 20705 \\ Robert J. Griesbach \\ U.S. Department of Agricultural, Agricultural Research Service, Beltsville Agricultural Research \\ Center, Floral and Nursery Plant Research Unit, U.S. National Arboretum, Beltsville, MD 20705
}

\begin{abstract}
AdDitional Index words. breeding, heritability, leaf, linkage, plant height
Abstract. Considerable diversity exists in Capsicum L. germplasm for fruit and leaf shape, size, and color as well as plant habit. Using $F_{1}, F_{2}$, and backcross generations developed from diverse parental stocks, this report describes the inheritance patterns and relationships between unique foliar characters and diverse fruit and plant habit attributes. Our results demonstrate that pepper fruit color, shape, and fruit per cluster were simply inherited with modifying gene action. Broad-sense heritability for fruit color and shape and fruit per cluster was high, whereas narrow-sense heritability for these characters was moderate to low. Although fruit clustering was simply inherited, the number of fruit per cluster exhibited a quantitative mode of inheritance. High fruit counts per cluster were linked with red fruit color and anthocyanin pigmented foliage. Fruit shape was linked with immature fruit color and inherited independently of mature fruit color. Leaf color, length, and plant height were quantitatively inherited. Leaf shape did not vary, but leaf length varied and was positively correlated with leaf width. Broad-sense heritability for leaf characters, including leaf length, leaf width, and leaf color, was high. With the exception of leaf width, which exhibited low narrow-sense heritability, high narrow-sense heritability for leaf characters denoted additive gene action. Plant height displayed high broad-sense heritability. Moderate narrow-sense heritability suggested that additive effects also influence plant height. Analysis of segregating populations demonstrated that red and orange fruit color can be combined with all possible leaf colors from green to black. These results provide new data to clarify and extend available information on the inheritance of Capsicum fruit attributes and provide new information on the genetic control of leaf characters and plant habit.
\end{abstract}

Peppers or Capsicum have a long history as both a culinary and ornamental plant (Greenleaf, 1986). In recent years, there has been a demand for increasing the diversity within both culinary and ornamental types (Stommel and Bosland, 2006). Within the genus Capsicum, there is an abundance of genetic diversity for plant habit, fruit and leaf characteristics to meet the demands for creating new types.

In Capsicum, over 290 genes have been identified for unique horticultural characteristics (Daskalov and Poulos, 1994; Lippert et al., 1965, 1966; Wang and Bosland, 2006). Attributes conditioned by many of these genes vary in their usefulness for crop improvement and the inheritance pattern for many of these genes has not been completely determined. For example, the anthocyanin pigment found in Capsicum leaves, flowers, and immature fruit is delphinidin-3-p-coumaroyl-rutinoside-5-glucoside (Lightbourn et al., 2008). Anthocyanin production was reported to be influenced by an incompletely dominant gene $(A)$ called Anthocyanin and a second modifying gene $(M o A)$ called Modifier of A (Deshpande, 1933; Peterson, 1959). However, the $A$ locus does not encode an enzyme in the anthocyanin

Received for publication 2 Jan. 2008. Accepted for publication 25 Feb. 2008. This work was supported by a Cooperative Research and Development Agreement (58-3K95-5-1074) with McCorkle Nursery and Kerry's Bromeliad Nursery.

Mention of trade names or commercial products is solely for the purpose of providing specific information and does not imply recommendation or endorsement by the U.S. Department of Agriculture.

${ }^{1}$ Corresponding author. E-mail: john.stommel@ars.usda.gov. biosynthetic pathway. It encodes a $M y b$ transcription factor $\left(M y b_{A}\right)$ that is absent in genotypes that do not accumulate anthocyanin (Borovsky et al., 2004). None of the Capsicum anthocyanin structural genes have yet been identified. There are a number of genes (al-1, al-2, al-3, al-4, and al-5) that result in anthocyaninless tissue (Csillery, 1980), but these genes have not yet been ascribed a regulatory or structural gene function.

To develop a breeding program, knowledge of gene interaction is essential for success. For example, the $A$ locus for anthocyanin pigmentation is genetically linked to the $O$ locus for round fruit shape (Peterson, 1959). This information tells us that it would be difficult to create a round anthocyanin-free fruit using an $a a$ genotype. An alternate breeding approach using a different anthocyanin-free genotype would be more successful. The genetic information for such an alternate approach, however, is lacking.

From Capsicum annuum L. accessions, we have developed new breeding lines and cultivars that combine unique foliar attributes with diverse fruit and plant habit attributes (Stommel and Griesbach, 1993, 2004, 2005, 2008a, 2008b). This article describes the inheritance patterns and relationships between these horticulturally desirable characteristics.

\section{Materials and Methods}

Plant material. Two inbred U.S. Department of Agriculture $C$. annuum breeding lines (G02C52, G02C17) with divergent phenotypes were selected as parents for producing 
$F_{1}$ and segregating $F_{2}$ and backcross generations. These lines exhibited dichotomy in plant habit and foliage and fruit shape and pigmentation (Table 1). Plants of line G02C52 (P1) are short in stature relative to $\mathrm{G} 02 \mathrm{C} 17$ (P2), display indeterminate growth, and produce green foliage and solitary Tabasco-type upright-oriented fruit. Immature fruit are green and mature to orange. Plants of $\mathrm{G} 02 \mathrm{C} 17$ are tall in stature relative to $\mathrm{G} 02 \mathrm{C} 52$, exhibit determinate growth, and produce black foliage and upright clusters of round fruit. Immature fruit are black and mature to red. G02C17 is a progenitor of the ornamental pepper cultivar Black Pearl (Stommel and Griesbach, 2005). The respective populations were developed by crossing greenhousegrown plants using standard emasculation practices.

Progeny of each population were grown in the greenhouse using standard production practices. Six-week-old plants of each genotype were transplanted to field plots in late May 2006 at the Beltsville Agricultural Research Center, Beltsville, MD, into Keyport fine loam soil, a clayey, mixed, mesic Acquic Hapludult. Field-grown plants were spaced at $0.4-\mathrm{m}$ intervals in single rows on polyethylene-covered raised beds with beds positioned on $1.5-\mathrm{m}$ centers with trickle irrigation. Pest control and fertilizer regimes followed standard horticultural practices for pepper production in Maryland (University of Maryland, 2000).

Plant, leaf, and fruit analysis. Plant height and diameter were recorded for individual field-grown plants in Sept. 2006 ( $\mathrm{n}=5$ for individual $\mathrm{P} 1, \mathrm{P} 2$, and $\mathrm{F}_{1}$ generations; $\mathrm{n}=96,99$, and 62 for $\mathrm{F}_{2}, \mathrm{BCP} 1$, and $\mathrm{BCP} 2$ generations, respectively). Coincident with measurement of plant height and diameter, fully expanded leaves and ripe fruit exhibiting characteristic orange to red fruit color were collected and digitally photographed under natural daylight on a neutral gray background. A rule was included in the photograph. The images were then color-corrected to the neutral gray background. Detailed measurements, including leaf length, leaf width at the midpoint, fruit length, fruit width at the midpoint, and number of fruit per cluster, were made from the images. The results for individual plants from respective generations are reported as the mean and SE of five different leaf and fruit samples collected from the same plant.

Color measurements were made from digital images of leaves and mature fruit using Paint Shop Pro ${ }^{\mathrm{TM}}$ Photo IX (Corel Corp., Ottawa, Canada). The individual red, green, and blue colors (RGB) for each sample were measured using the "Material Properties" function of the program. For each sample, 10 RGB values were obtained and the average used. Immature fruit colors were scored visually in the field as black or green.

To more accurately determine the difference between mature orange and red fruit color, the RGB data were transformed using the equation (R-G)/(R-B). Using transformed data, the reddest fruit had a value near 1.0 , whereas the most orange fruit had a value near 0.5 . The leaf color data were transformed using the formula $\mathrm{R}+\mathrm{B}-\mathrm{G}$. Using transformed data, the blackest leaves had a value near 60 , whereas the greenest leaves had a value near 4 .

Heritability estimates. Broad-sense heritability $(\mathrm{H})$ was calculated as the ratio of the genotypic variance over the phenotypic variance of the $F_{2}$ generation (Allard, 1960):

$$
\mathrm{H}=\left\{\mathrm{V}_{\mathrm{F} 2}-\left[1 / 3\left(\mathrm{~V}_{\mathrm{P} 1}+\mathrm{V}_{\mathrm{P} 2}+\mathrm{V}_{\mathrm{F} 1}\right)\right]\right\} / \mathrm{V}_{\mathrm{F} 2}
$$

Narrow-sense heritability $\left(\mathrm{h}^{2}\right)$ was estimated using $\mathrm{F}_{2}$ and backcross generation variance components as described by Mather (1949) and Warner (1952):
Table 1. Mean values and SDs for mature pepper fruit color, fruit length/fruit diameter at midpoint, number of fruit per cluster, leaf color, leaf length, leaf width, plant height, and plant diameter in parental, $\mathrm{F}_{1}, \mathrm{~F}_{2}$, and backcross generations from the Capsicum annuum cross G02C52 × G02C17.

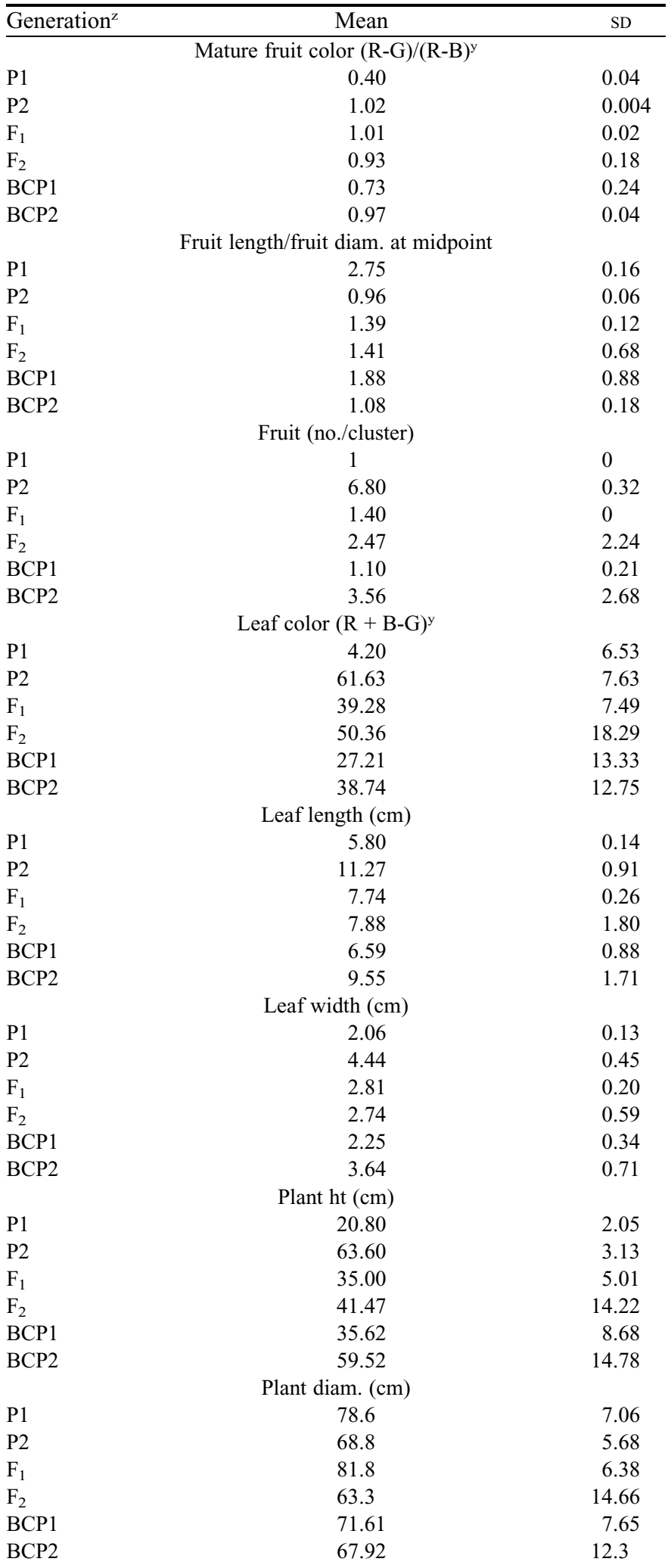

${ }^{2} \mathrm{P} 1=\mathrm{G} 02 \mathrm{C} 52 ; \mathrm{P} 2=\mathrm{G} 02 \mathrm{C} 17 ; \mathrm{BCP} 1$ and $\mathrm{BCP} 2$ are the backcross of the $\mathrm{F}_{1}$ to $\mathrm{G} 02 \mathrm{C} 52(\mathrm{P} 1)$ and $\mathrm{G} 02 \mathrm{C} 17$ (P2), respectively.

${ }^{\mathrm{y}} \mathrm{R}, \mathrm{G}$, and $\mathrm{B}=$ red, green, and blue, respectively. 


$$
\mathrm{h}^{2}=\left(2 \mathrm{~V}_{\mathrm{F} 2}-\mathrm{V}_{\mathrm{B} 1}-\mathrm{V}_{\mathrm{B} 2}\right) / \mathrm{V}_{\mathrm{F} 2}
$$

For broad-sense and narrow-sense heritability formulas, $\mathrm{V}_{\mathrm{P} 1}, \mathrm{~V}_{\mathrm{P} 2}, \mathrm{~V}_{\mathrm{F} 1}$, and $\mathrm{V}_{\mathrm{F} 2}$ correspond to the variance of respective morphological characters described for P1 (G02C52), P2 (G02C17), $F_{1}$, and $F_{2}$ generations, respectively. $V_{B 1}$ and $V_{B 2}$ correspond to the variance of the $\mathrm{F}_{1}$ backcrossed to $\mathrm{P} 1$ and $\mathrm{P} 2$, respectively. Variance components were estimated using SigmaStat (version 3.11; Systat Software, San Jose, CA).

\section{Results and Discussion}

In pepper, there are numerous studies that associate gene names to specific traits (Wang and Bosland, 2006). In many of these studies, the inheritance of morphological traits was not described in detail. We have observed that many of these traits were not simply inherited as suggested, but were influenced by the action of modifying genes. We describe additional variation in fruit and foliar morphology that exhibits a quantitative mode of inheritance.

We observed that immature black fruit color is controlled by a single dominant gene. The $\mathrm{F}_{1}$ generation of G02C52 (immature green fruit) and $\mathrm{G} 02 \mathrm{C} 17$ (immature black fruit) produced black fruit (Table 1). The backcross generation to G02C52 produced the expected 1:1 ratio for a single gene (48 green to 51 black; $\left.\chi^{2}=0.090, P>0.95\right)$. The $\mathrm{F}_{2}$ generation approached the expected $3: 1$ ratio (54 green to 142 black; $\chi^{2}=0.670, P>$ $0.50)$. This is consistent with the literature as discussed in the introduction (Borovsky et al., 2004; Deshpande, 1933; Ikeno, 1913; Peterson, 1959).

The broad-sense heritability for immature black fruit color was 1.0 (Table 2) indicating that there was a large genetic component and no environmental component. A moderate narrow-sense heritability [0.56 (Table 2)] for immature fruit color suggested that there are a small number of minor genes that could influence color. The very high broad-sense heritability and moderate narrow-sense heritability denote that it should be straightforward to create either black- or greencolored immature fruit. This is in agreement with our preliminary observations during initial phases of our breeding program to develop new pepper ideotypes for ornamental and dualpurpose culinary/ornamental applications (Stommel and Griesbach, 1993, 2005, 2008a, 2008b). We found that it was quite easy to create solid black-fruited ideotypes.

In addition to violet- to black-colored immature fruit, gradations in unripe pepper fruit color may vary from green to ivory. Green to ivory immature fruit color is attributed to a series of loci (Odland and Porter, 1938). Ivory or sulfury white fruit color is conditioned by the sulfur white $\left(s w_{1}\right)$ locus. Lettuce or yellow green color is attributed to the $s w_{2}$ and dark green or cedar green color is conditioned by $s w_{3}$.

Unlike the discrete color of immature fruit, mature fruit varied in color from red to orange. Using transformed RGB data, the reddest fruit had the highest value $(\approx 1.0)$, whereas the most orange fruit had the lowest value $(\approx 0.4)$. The $\mathrm{F}_{1}$ generation of $\mathrm{G} 02 \mathrm{C} 52$ (mature orange fruit) and $\mathrm{G} 02 \mathrm{C} 17$ (mature red fruit) was red (Table 1 ). The $\mathrm{F}_{2}$ generation varied in color from orange through red (Fig. 1A) with two somewhat distinct groups of plants clustering around each parental mean. Interestingly, within this population, a large number of plants had fruit that were redder than $\mathrm{G} 02 \mathrm{C} 17$. As expected, the two
Table 2. Estimates of broad-sense heritability and narrow-sense heritability for pepper fruit length/fruit diameter at midpoint, mature fruit color, immature fruit color, number of fruit per cluster, leaf color, leaf length, leaf width, and plant height in Capsicum annuum populations developed from the cross of G02C52 × G02C17.

\begin{tabular}{lcc}
\hline $\begin{array}{l}\text { Character } \\
\text { Fruit length/fruit diam. }\end{array} \quad \begin{array}{c}\text { Broad-sense } \\
\text { at midpoint }\end{array}$ & $\begin{array}{c}\text { Narrow-sense } \\
\text { heritability }^{\mathrm{z}}\left(\mathrm{h}^{2}\right)\end{array}$ \\
$\quad \begin{array}{l}\text { Mature fruit color } \\
\text { (R-G)/(R-B) }\end{array}$ & 0.97 & 0.25 \\
Immature fruit color & 0.97 & 0.14 \\
Fruit (no./cluster) & 1 & 0.56 \\
Leaf color & 0.99 & 0.55 \\
Leaf length & 0.84 & 0.98 \\
Leaf width & 0.91 & 0.86 \\
Plant ht & 0.76 & 0.23 \\
\end{tabular}

${ }^{\mathrm{z}}$ Broad-sense heritability estimated according to the methods of Allard (1960). Narrow-sense heritability estimated according to the formula of Mather (1949) and Warner (1952).

${ }^{y} \mathrm{R}, \mathrm{G}$, and $\mathrm{B}=$ red, green, and blue, respectively.

backcross generations segregated into subpopulations whose means closely matched the parental means (Fig. 1A).

Mature fruit color is the result of reduction in chlorophyll and anthocyanin pigmentation and an accumulation of carotenoid pigments. There are a number of genes that influence the accumulation of over 30 different carotenoids in mature fruit (Matus et al., 1991). Capsanthin and capsorubin are the major pigments in red fruit; whereas violaxanthin and $\beta$-carotene are the major pigments in orange fruit (Gross, 1991). $\beta$-carotene accumulation is controlled by the $B$ (Beta-carotene) locus and a second modifying $T$ (High beta-carotene) locus (Brauer, 1962). Capsanthin and capsorubin accumulation is controlled by the $Y$ (Yellow mature fruit color) locus and two modifying loci C1 (Carotenoid pigment inhibitors) and C2 (Boswell, 1937; Smith, 1950). The $Y$ locus has been assigned a function (capsanthincapsorubin synthase) and was mapped to chromosome 6 (Popovsky and Paran, 2000). The C2 locus has also been assigned a function (phytoene synthase) and was mapped to chromosome 4 (Huh et al., 2001). Because the $B$ locus controls a step in the biosynthetic pathway (orange fruit) that precedes the step (red fruit) controlled by the $Y$ locus (Thorup et al., 2000), red fruit is expected to be dominant over orange fruit. Our data support the contribution of a major gene that influences mature fruit color but also suggests the influence of modifiers that cause color gradation within fruit color classes. A novel recessive gene, $b c$, has also been described that elicits high fruit $\beta$-carotene content by blocking the hydroxylation of $\beta$-carotene to $\beta$-cryptoxanthin (Chalukova et al., 1993; Daskalov et al., 1995).

Similar to immature fruit color, the broad-sense heritability for mature fruit color was high [0.97 (Table 2)] denoting a large genetic component and a small environmental component. A low narrow-sense heritability $[0.14$ (Table 2)] indicated that additive genetic variance is low and epistatic effects influence mature fruit color. This is in agreement with our breeding observations (Stommel and Griesbach, 1993, 2004, 2005, 2008a, $2008 \mathrm{~b}$ ). We found that it was quite straightforward to select red and red-orange-fruited ideotypes but quite difficult to develop 

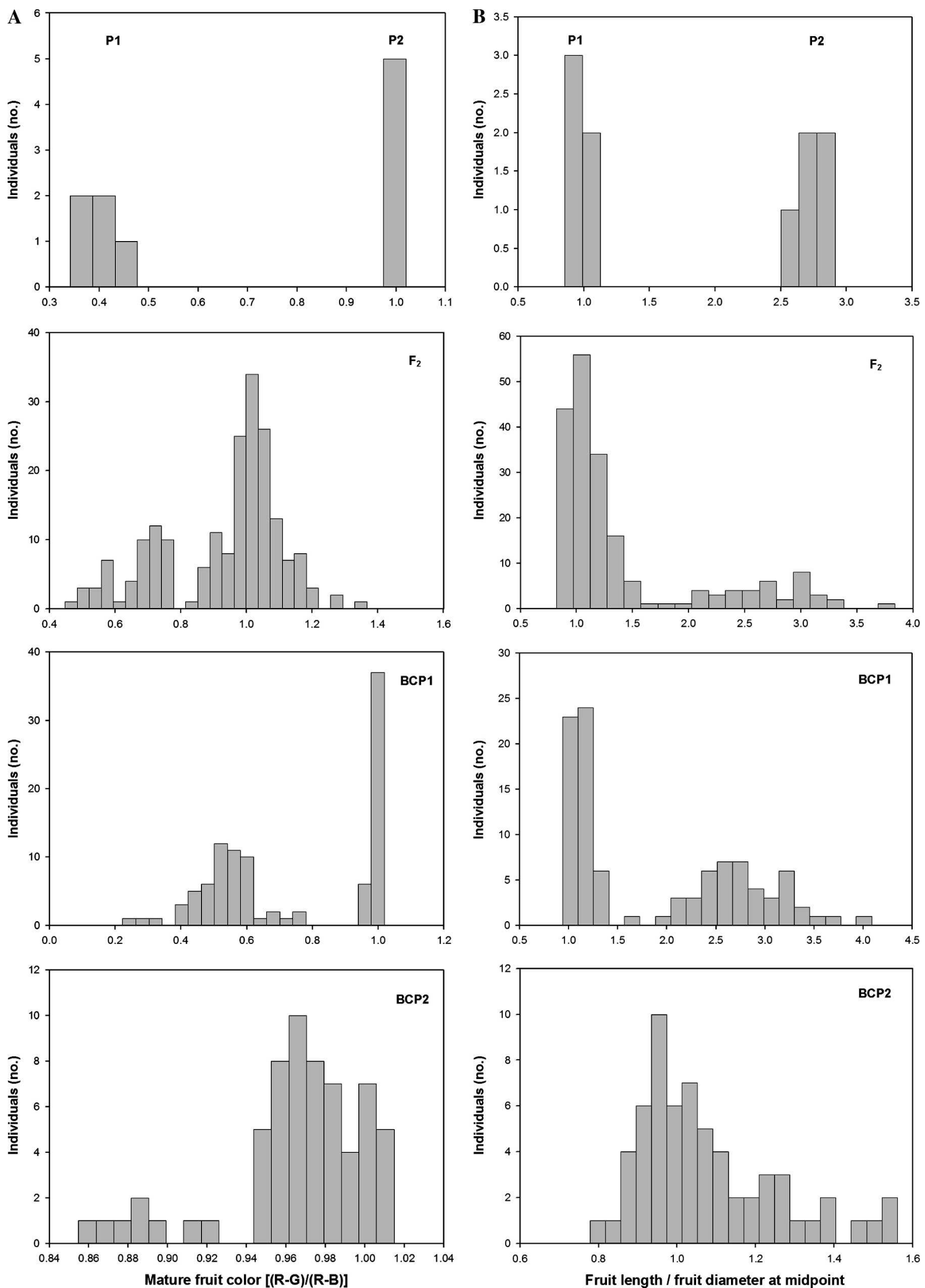

Fig. 1. Population distributions for pepper fruit, leaf and plant habit attributes in $\mathrm{P} 1, \mathrm{P} 2, \mathrm{~F}_{2}$, and backcross generations from the cross of $\mathrm{G} 02 \mathrm{C} 52 \times \mathrm{G} 02 \mathrm{C} 17$ [BCP1 and BCP2 are the backcross of the $\mathrm{F}_{1}$ to G02C52 (P1) and G02C17 (P2), respectively]. (A) Mature fruit color; (B) fruit length/fruit diameter at midpoint; (C) fruit (no./cluster); (D) leaf length; (E) leaf width; (F) plant height; and (G) leaf color (R, G, and B = red, green, and blue, respectively). 

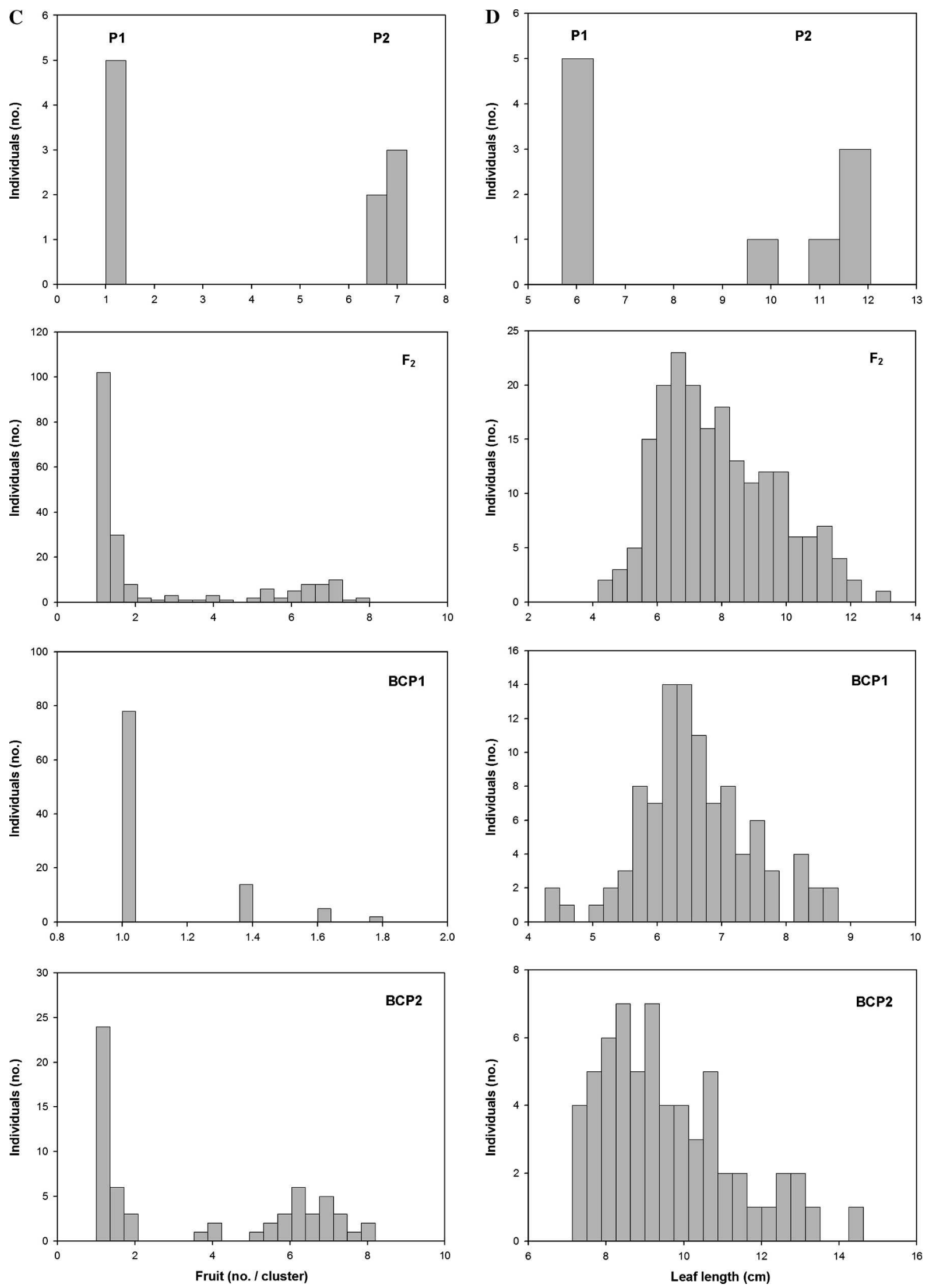

Fig. 1. (Continued). 

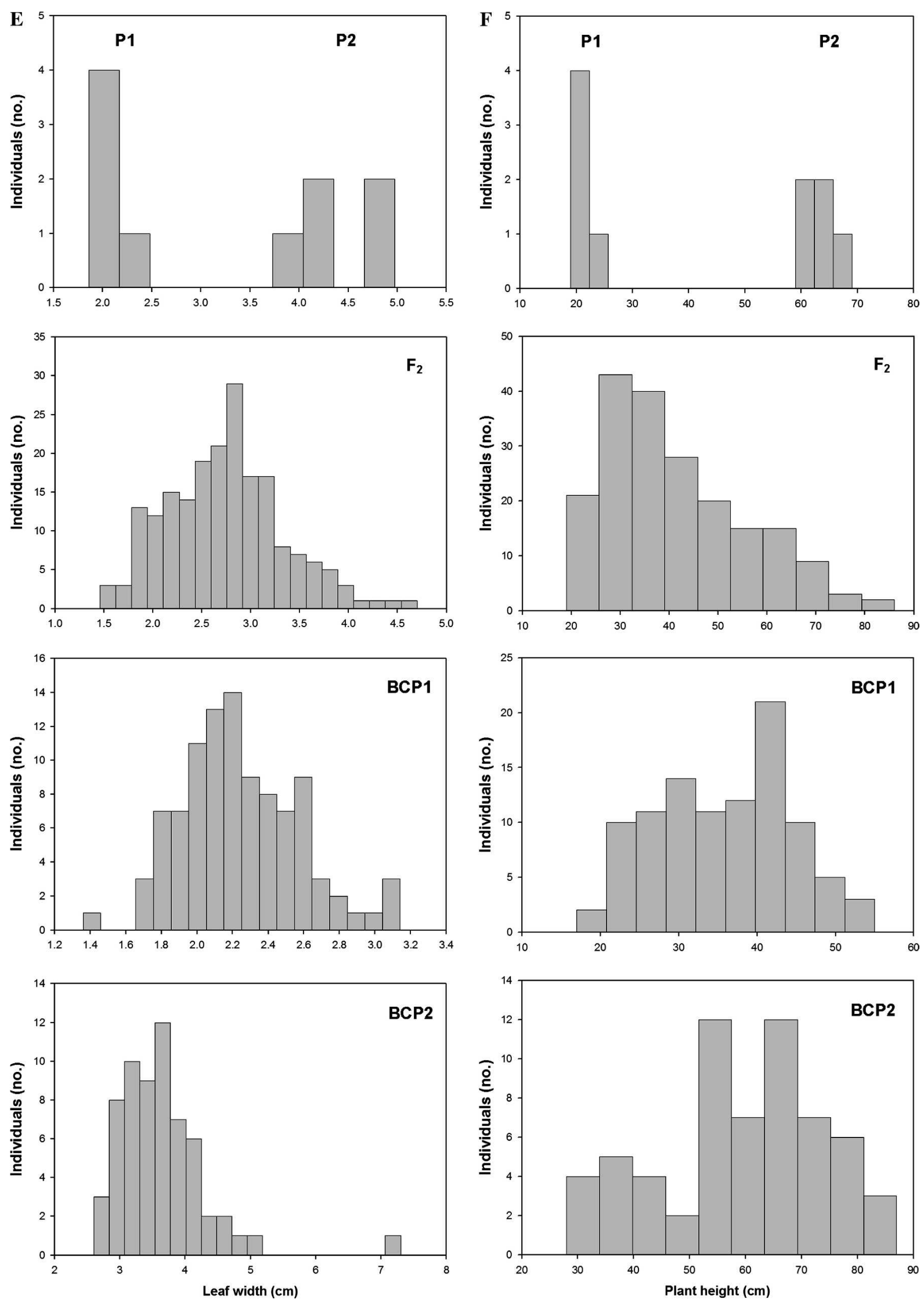

Fig. 1. (Continued). 

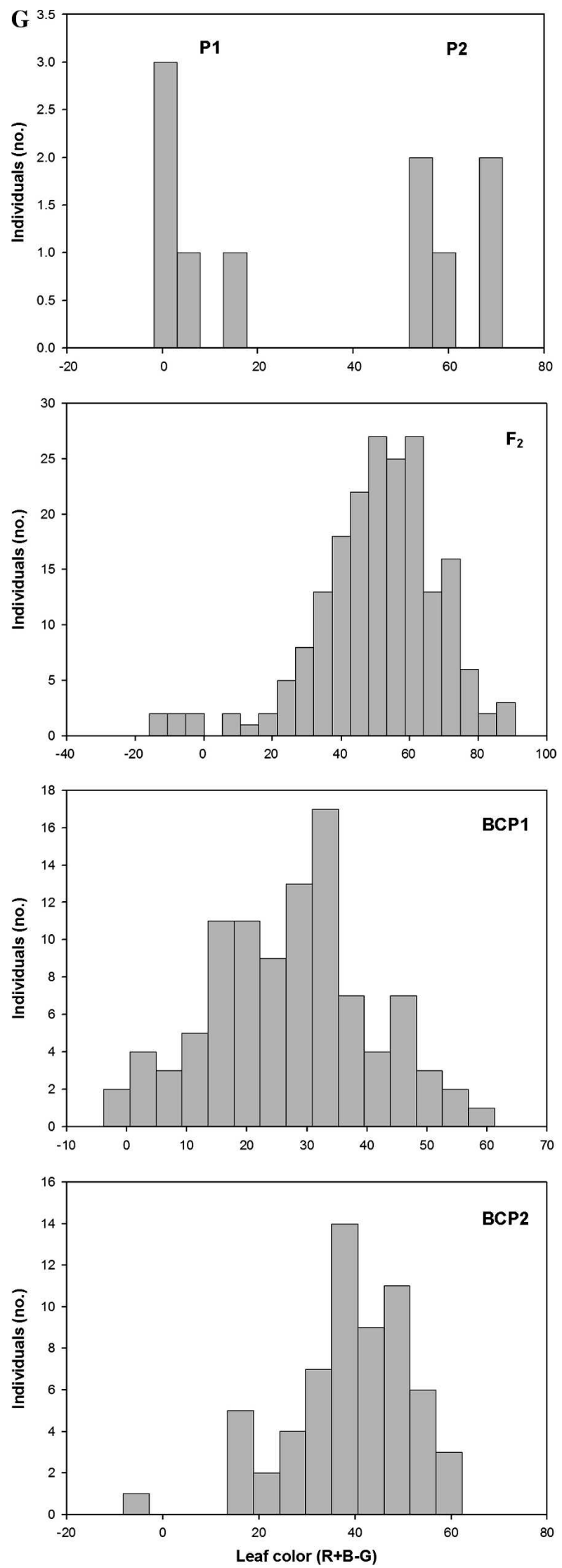

Fig. 1. (Continued). pure orange-fruited ideotypes. This may be attributed to the genetic background of the parental lines. In other genetic backgrounds, we have obtained true orange lines, suggesting that additional modifying genes may be present.

Additional genetic variation for novel mature pepper fruit color has been described. Retention of chlorophyll in mature fruit conditioned by the chlorophyll retainer gene $(c l)$, combined with red $(Y)$ or yellow $(y)$ carotenoid-mediated pigmentation, results in brown and olive green mature fruit color, respectively (Smith, 1948, 1950). Retention of violet anthocyanin pigments in combination with carotenoids that accumulate in ripening fruit provides additional color gradation (Stommel and Bosland, 2006).

Fruit shape was determined by dividing fruit length by fruit diameter at the midpoint. The $F_{1}$ generation of G02C52 (elongate fruit; fruit length/fruit width at midpoint $=2.75$ ) and $\mathrm{G} 02 \mathrm{C} 17$ (round fruit; fruit length/fruit width at midpoint = 0.96 ) was intermediate in fruit shape (fruit length/fruit width at midpoint $=1.39$; Table 1). The distribution of plants within the $\mathrm{F}_{2}$ generation was skewed toward round fruit (Fig. 1B). Similar distribution patterns were observed in both backcross generations, indicating that round fruit was dominant over elongate fruit. A single locus, $O$ (Oblate), has been designated for control of round fruit shape (Kaiser, 1935; Khambanonda, 1950; Peterson, 1959). Khambanonda (1950) found $O$ to be only partially dominant with $\approx 30$ minor genes modifying round to elongate fruit shape, whereas Peterson found it to be completely dominant for round fruit. Our results more closely follow those of Khambanonda.

The broad-sense heritability for fruit shape was 0.97 (Table 2 ), indicating that there was a large genetic component and a small environmental component for fruit shape. The narrowsense heritability was 0.25 (Table 2). The results suggest that one can effectively select for either round or elongate fruit but that progress will be slow. The low narrow-sense heritability is in agreement with Khambanonda (1950) who also concluded that there are minor genes that affect fruit shape. These genes result in a continuous range of fruit shapes for varied applications in culinary and ornamental applications.

Our data indicate that fruit shape (fruit length/fruit diameter at midpoint) is linked to immature fruit color (Fig. 2A). In the $\mathrm{F}_{2}$ generation, plants with immature black fruit were restricted to the more rounded shapes, whereas green fruit could be found with any fruit shape. This is in agreement with Peterson (1959) who demonstrated that the $A$ and $O$ loci were linked with $6.5 \%$ recombination. Our data are also consistent with $6.5 \%$ recombination. We observed five $\mathrm{F}_{2}$ plants $(3.5 \%)$ with black and elongate fruit (Fig. 2A). Recently, a major QTL for fruit shape $\left(f_{s} 10.1\right)$ was found on chromosome 10 , the same chromosome where the $A$ locus is located (Ben Chaim et al., 2003a, 2003b).

Population distributions indicated that fruit shape (fruit length/fruit diameter at midpoint) and mature fruit color are not linked (Fig. 2B). In the $F_{2}$ generation, plants with round fruit had a continuous variation in color from red to orange. Plants with elongated fruit were not as common but did vary in color from red to orange. We have been able to create red and orange fruit in a range of shapes (Stommel and Griesbach, 2004, 2005, 2008a, 2008b).

Either a single fruit or a cluster of fruit can develop at each stem node. In this study, we determined that nonclustered (one fruit per node) versus clustered (multiple fruit per node) fruiting was controlled by a single dominant gene. The recessive 

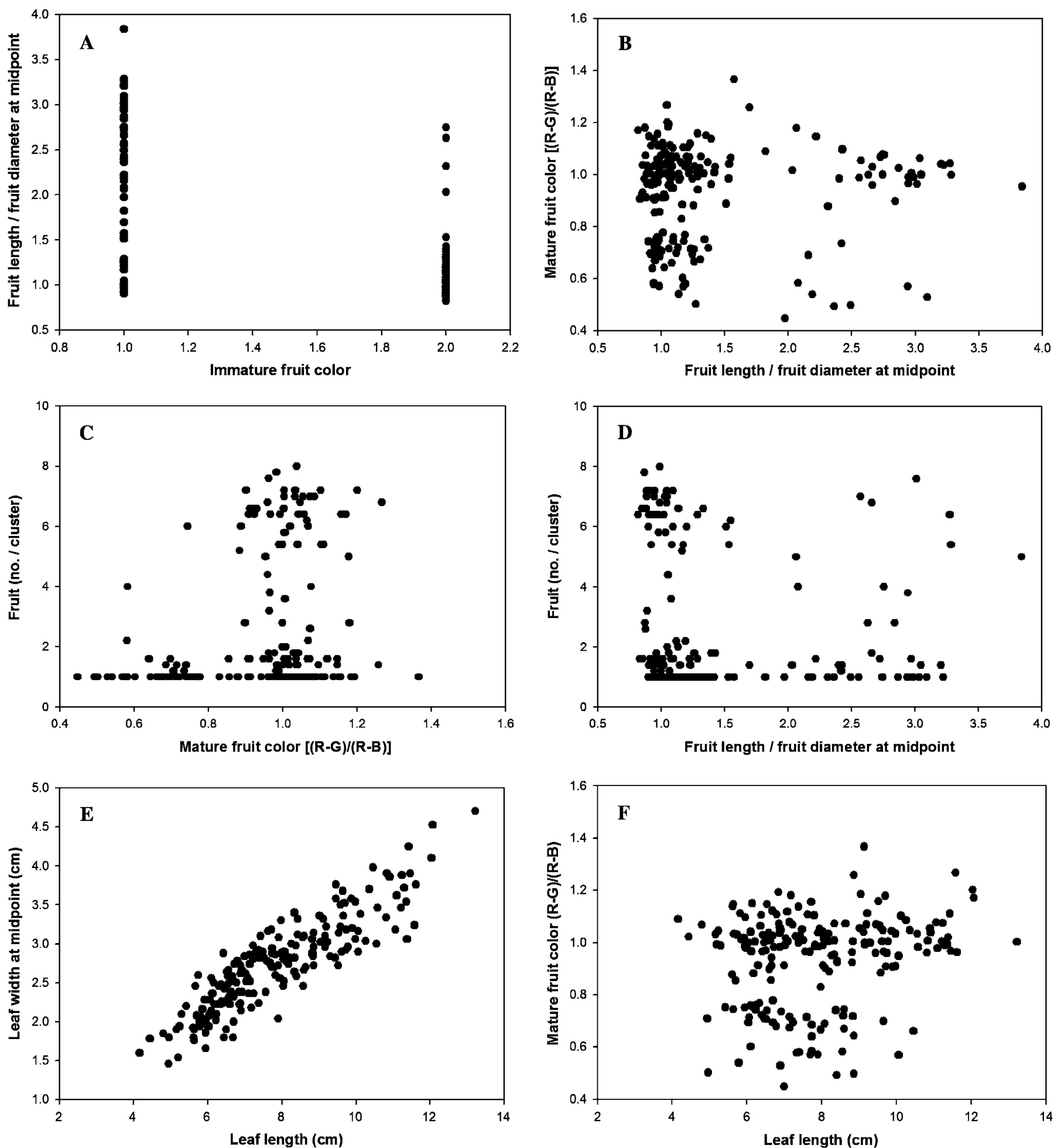

Fig. 2. $\mathrm{F}_{2}$ generation population distributions for pepper fruit, leaf and plant habit attributes from the cross of G02C52 $\times$ G02C17. (A) Immature fruit color versus fruit length/fruit diameter at midpoint; (B) fruit length/fruit diameter at midpoint versus mature fruit color; (C) mature fruit color versus fruit (no./cluster); (D) fruit length/fruit diameter at midpoint versus fruit (no./cluster); (E) leaf length versus leaf width; (F) leaf length versus mature fruit color; (G) plant height versus mature fruit color; $(\mathbf{H})$ leaf length versus plant height; (I) leaf length versus leaf color; (J) mature fruit color versus leaf color; (K) fruit length/fruit diameter at midpoint versus leaf color; and (L) leaf color versus fruit (no./cluster) (R, G, and B = red, green, and blue, respectively).

condition resulted in clustered fruit (Fig. 1C). The $\mathrm{F}_{2}$ generation approached the expected $3: 1$ ratio (53 clustered to 143 nonclustered; $\chi^{2}=0.435, P>0.50$ ) for a single dominant gene. The backcross to the recessive parent produced the expected $1: 1$ ratio ( 32 clustered to 30 nonclustered; $\chi^{2}=0.064, P>0.95$ ) for a single dominant gene.

Whereas nonclustered versus clustered fruit was simply inherited, the number of fruit in a cluster varied from one to 

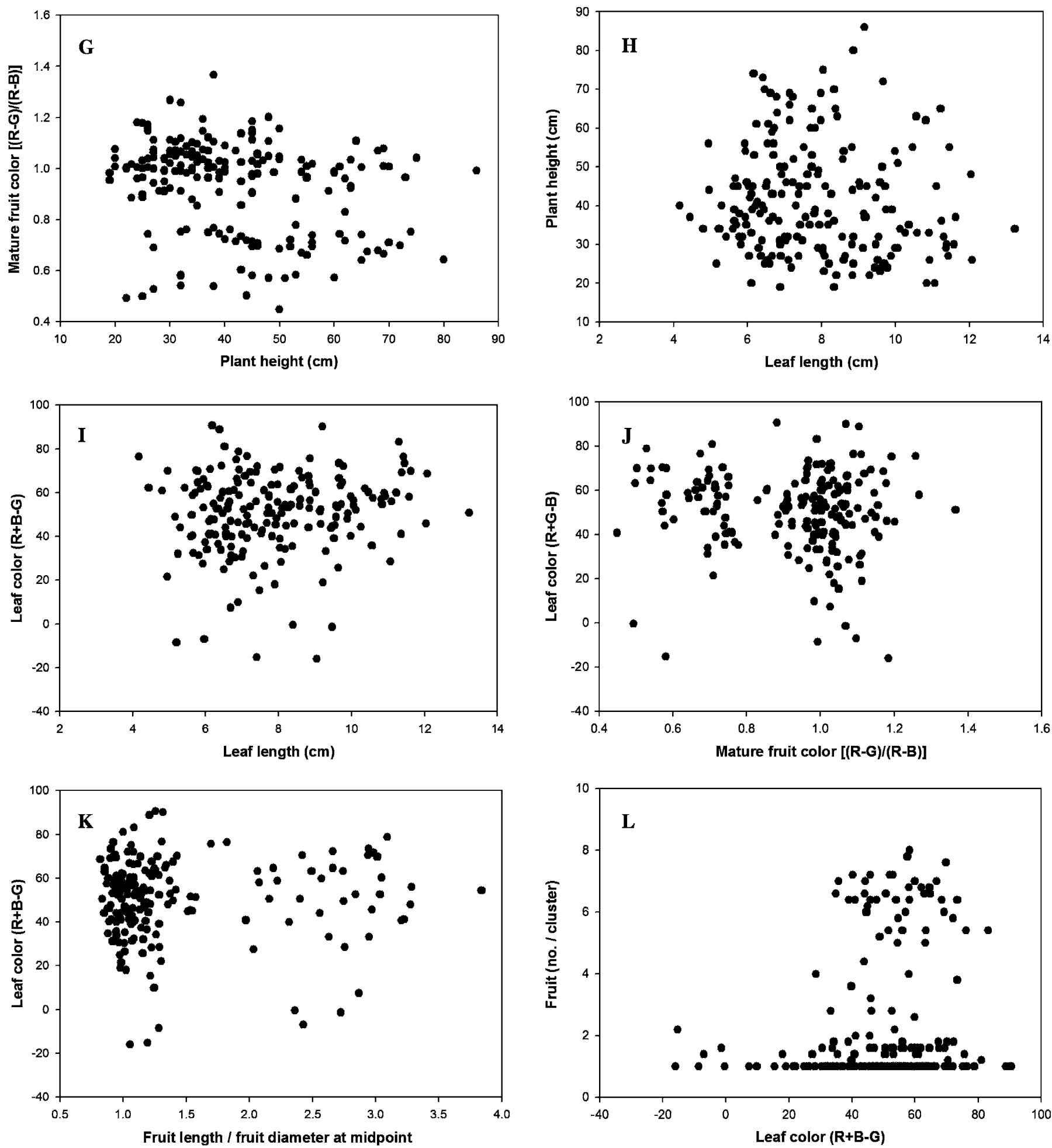

Fig. 2. (Continued).

nine and was quantitatively inherited. The broad-sense heritability for fruit per cluster was 0.99 (Table 2), indicating that there was a very large genetic component and almost no environmental component. The narrow-sense heritability was 0.55 (Table 2) indicating that there is a moderate number of minor genes that influence the number of fruit per cluster. The high broad-sense heritability and moderate narrow-sense her- itability suggests that it should be relatively straightforward to develop plants with an increased number of fruit per cluster.

The fasciculation locus $(F a)$ has been identified that effects fruit clustering (Lippert et al., 1965, 1966). This locus also affects internode length resulting in short, compact plants. Because in our studies the growth habit of plants with clustered fruit was not affected, clustering was mostly likely not the result 
of $\mathrm{Fa}$ expression. We found that fruit clustering was linked to mature fruit color. $\mathrm{F}_{2}$ plants with the highest number of fruit per cluster generally had red-colored fruit (Fig. 2C). Conversely, there appeared to be no linkage between the number of fruit per cluster and fruit shape (Fig. 2D). Heavily clustered fruit can produce striking ornamental displays (Stommel and Bosland, 2006) and have been considered in new ideotypes to enhance fruit yield (Greenleaf, 1986).

Leaves of G02C52 were considerably smaller than those of G02C17 (Table 1). Leaf length and leaf width at the midpoint of $F_{1}$ and $F_{2}$ generations was intermediate to the two parental genotypes (Fig. 1D-E). Backcrosses of the $\mathrm{F}_{1}$ to the respective parents shifted mean leaf length and width values in the direction of parental means. With the exception of a unique outlier with leaf width that far exceeded that of either parent, population means and distributions denoted a quantitative mode of inheritance for these morphological characters. The presence of additive effects was supported by high narrowsense heritability estimates, particularly for leaf length $\left(\mathrm{h}^{2}=\right.$ 0.86) (Table 2). Broad-sense heritability for leaf length and width were relatively high (Table 2) indicating that genotype effects were of greater importance in comparison with environmental influence.

Overall, leaf length was positively correlated with leaf width (Pearson correlation coefficient, $\mathrm{r}=0.89 ; P<0.001$ ) (Fig. 2E). Leaf shape, described as the ratio of leaf length over leaf width at the midpoint, was similar for the two parental genotypes $(\mathrm{P} 1=2.80 \pm 0.22 ; \mathrm{P} 2=2.55 \pm 0.17)$. Whereas our observations indicate that effective selection can be practiced for overall leaf size, it may be more difficult to alter leaf shape. There was no relationship between leaf length and mature fruit color (Fig. $2 \mathrm{~F})$. Hence, varying fruit colors can be combined with different sized leaves in new ideotypes for ornamental and dual culinary/ ornamental use (Stommel and Griesbach 1993, 2004, 2005, 2008a, 2008b). A similar relationship was evident for leaf width. Because leaf length and width were correlated, only leaf length associations with other morphological characters are presented.

Over 30 leaf mutants have been identified in Capsicum (Wang and Bosland, 2006). Surprisingly, these mutants afford little insight into the inheritance and gene action that influences leaf morphology of typical $C$. annuum breeding material such as that reported here. A number of these mutants, however, offer potential for introducing desirable variation into breeding populations. Genes for altering leaf shape include anv (Augustifolia variegada; Daskalov and Poulos, 1994) that elicits production of long and narrow leaves and round leaf $(r l-1, r l-2, r l-3$; Aniel Kumar et al., 2001; Csillery, 1983; Greenleaf and Hearn, 1976), which causes leaf rounding by reducing the length, but not the width, of leaves. Other potentially useful mutants for ornamental applications include the frilly gene ( $f r$; Csillery, 1980), which elicits undulating leaf margins and rugose (ru) that causes dark green rugose or savoyed leaves (Csillery, 1983). Most other described leaf morphology genes have little promise as a result of gross leaf deformity or deleterious pleiotropic effects. The small leaf ( $\mathrm{sm}-l)$ mutant, for example, reduces leaf size but results in fewer flowers and fruit, poor seed set, and partial sterility (Aniel Kumar et al., 2001).

Broad-sense heritability for plant height in the populations described here was high [0.93 (Table 2)]. Population distributions suggested the presence of multiple genes that condition plant height (Table 1; Fig. 1F). Height of $F_{1}$ and $F_{2}$ generations was intermediate between parental types. Whereas the population mean of the backcross to G02C52 (BCP1 generation) maintained intermediate plant height, the mean plant height of the backcross to the taller G02C17 parent (BCP2 generation) approximated the height of G02C17 plants, suggesting dominance for tall plant stature. A moderate narrow-sense heritability estimate $(0.55)$ for plant height denoted the presence of additive effects for this character and a likely contribution of epistatic effects to plant height as well in these genetic backgrounds. No relationship was evident between plant height and mature fruit color or leaf length (Fig. 2G-H) indicating that genotypes with varied plant height, leaf size, and mature fruit color could be developed.

These observations on plant stature are in agreement with our preliminary observations on plant height during initial phases of the breeding program to develop new pepper ideotypes for ornamental and dual culinary/ornamental use (Stommel and Griesbach, 2008b). The results indicate that effective gains can be made in selection of genotypes with varied plant stature.

The majority of the pepper plant height mutants that have been described result in dwarf phenotypes. Recessive genes for dwarf plant stature, $d w 1$ and $d w 2$ (dwarf), reduce plant size substantially (12 to $15 \mathrm{~cm}$ and 15 to $20 \mathrm{~cm}$ mature height, respectively) and cause shortened internodes and thickened dark green leaves (Daskalov, 1974). Female fertility is reduced in $d w$ plants. Additional $d w$ genes with limited horticultural application have also been described $[d w-3$ to $d w-8$ (reviewed by Wang and Bosland, 2006)]. A single recessive gene, tall (tal) that results in increased plant height and reduced branching, flowering, and fruiting, was described from an induced C. annuum mutant (Aniel Kumar et al., 2001). Shriveled seed reduces the usefulness of this mutant.

A novel branching mutant, branchless $(b l)$, is responsible for branchless plants (Bergh and Lippert, 1964). Several major genes and numerous modifier genes influence compact growth habit, largely as a result of shortened internodes (Bergh and Lippert, 1975; McCamon and Honma, 1984). The recessive determinate gene $(d t)$ results in determinate growth. The recessive compact gene $(c t)$ increases the number of erect axillary shoots and reduces plant height by $\approx 50 \%$. Dominant $D t$ and $C t$ result in indeterminate growth and are epistatic to one another. A dominant gene, Su (suppressor of indeterminate growth), suppresses the epistatic effects of $C t$. Another gene, brl (braquitica latifoliata), causes shortened stem internodes as well as shortened leaf petioles (Daskalov and Poulos, 1994).

Assignment of simply inherited loci that condition tall to compact phenotypes is confounded by genetic background and environment. We did not observe clear bimodal distributions for plant height in segregating populations (Fig. 1F). Todorov (1992) observed that in crosses between dwarf and tall indeterminate selections, plant height was influenced by at least two to three genes with environmental effects having a stronger influence than genetic factors. Those observations, together with our results, support the action of additional genes that influence plant stature.

Using transformed RGB data to assess foliar anthocyanin pigmentation, the blackest leaves had a value near 60 (range, 54.5 to 71.3 ), whereas the greenest leaves had a value near 4 (range, -1.8 to 14.4). The cross between the green foliage line G02C52 and the black foliage line G02C17 resulted in $F_{1}$ progeny with color scores intermediate between the two 
parental lines (Table 1). The $\mathrm{F}_{1}$ color score corresponds to a greenish black foliage phenotype. Recombinants with extremes of green or black foliage pigmentation comparable to each of the parental lines were recovered in the $\mathrm{F}_{2}$ and BCP2 generations (Fig. 1G). Population distributions were skewed toward greenish black to black foliage phenotypes in the $F_{2}$ and BCP2 generations.

Broad-sense heritability for anthocyanin pigmented foliage was high [0.84 (Table 2)] indicating that a large proportion of the variance for leaf color is accounted for by heredity. Contrary to the presumed action of the incompletely dominant $A$ locus for anthocyanin pigmentation, true green foliage progeny $(a a)$ were underrepresented in the $\mathrm{F}_{2}$ (nine green : 187 anthocyanin pigmented) and the backcross to the green foliage G02C52 parent (BCP1 generation; 16 green : 83 anthocyanin pigmented). A single true green plant was recovered in the backcross to the black foliage parent G02C17 (BCP2 generation). Our results also do not support the sole action of $M o A$ in intensifying foliage anthocyanin pigmentation in the presence of $A$. The high heritability and range of color scores evident for anthocyanin-producing progeny suggest that inheritance of black foliar pigmentation is more complex involving the action of multiple genes. A high narrow-sense heritability estimate [0.98 (Table 2)] supports this assumption. The narrowsense heritability for foliar pigmentation exceeded the broadsense heritability estimate, likely as a result of experimental error. Clearly, additional genetic factors condition foliar anthocyanin pigmentation.

Development of black foliage ornamental pepper cultivars with diverse attributes necessitates crosses between black foliage and green foliage germplasm. Dependent on the genetic background of the respective parents, these crosses produce hybrid progeny with dark green to greenish black pigmented foliage. Consistent with the contribution of additive effects, development of true black foliage pepper ideotypes that combine unique fruit and plant habit characters necessitates further recurrent selection for intensity of foliar pigmentation (Stommel and Griesbach 2005, 2008a, 2008b).

$\mathrm{F}_{2}$ progeny distributions indicated that inheritance of leaf color was independent of leaf length, fruit color, and fruit shape (Fig. 2I-K). Therefore, genotypes with green-black mottled to true black leaves of varying size and fruit color and shapes can be obtained (Stommel and Griesbach, 1993, 2005, 2008a, $2008 b$ ). Whereas solitary fruit and clusters of two fruit were identified in both green and black foliage $\mathrm{F}_{2}$ progeny, clusters with greater than two fruit were restricted to individuals with anthocyanin-pigmented foliage in segregating populations developed from these parental lines (Fig. 2L). The results suggest linkage between the fruit cluster character and anthocyaninpigmented foliage.

In addition to anthocyanin-pigmented foliage mutants, numerous chlorophyll-related leaf mutants have been described in Capsicum. These include the aurea (aur) golden leaf color and flavi (Flv) yellow-green leaf mutants (Daskalov and Poulos, 1994), 12 xantha (xa-1 to $x a-12)$ mutants (Csillery, 1980, 1983; Lippert et al., 1965), 19 lutescens (lut-1 to lut-19) mutants (Csillery, 1980, 1983, 1985; Ma et al., 2001), three yellow top ( $y$ t-1 to $y t-3)$ mutants (Csillery, 1980, 1983), and 52 mosaic (mos-1 to mos-52) genes (Csillery, 1980, 1983). Unlike anthocyanin-pigmented pepper foliage, greenish yellow to yellow foliar pigmentation has not found successful commercial application because of poor plant vigor, lethality, and variable expression associated with many of the chlorophyll deficiency genes.

Additional variation for foliar pigmentation may be achieved by introgression of genes described in Capsicum for green/white foliar variegation. When expressed in genetic backgrounds where foliar anthocyanin occurs, purple/green/ white variegation occurs. Variegated mutants include four marbled ( $m-1$ to $m-4$ ) mutants (Daskalov, 1977; Lippert et al., 1965), plastid instability (pi) (Hagiwara and Oomura, 1947; Lippert et al., 1965) and chlorina (chl) (Kormos and Kormos, 1955; Lippert et al., 1965), and the allelic variegated mottled $\left(v g^{m}\right)$ and variegated virescent $\left(v g^{v}\right)$ loci (Lippert et al., 1965).

In summary, we found that 1) fruit color, shape, and fruit per cluster were simply inherited with modifying gene action; 2) whereas fruit clustering was simply inherited, the number of fruit per cluster exhibited a quantitative mode of inheritance; 3 ) fruit clustering was linked with red fruit color and anthocyaninpigmented foliage; 4) fruit shape was linked with immature fruit color and inherited independently of mature fruit color; 5) leaf color, length, and plant height were quantitatively inherited; 6) leaf shape did not vary, but leaf length varied and was positively correlated with leaf width; and 7) red and orange fruit color can be combined with all possible leaf colors from green to black. These results provide new data to clarify and extend available information on the inheritance of Capsicum fruit attributes and provide new information on the genetic control of leaf characters and plant habit.

\section{Literature Cited}

Allard, R.W. 1960. Plant breeding. Wiley, New York, NY.

Aniel Kumar, O., V. Anitha, K. Roseline Subhashini, and K.G. Raja Rao. 2001. Induced morphological mutations in Capsicum annuum L. Capsicum Eggplant Nwsl. 20:72-75.

Ben Chaim, A., Y. Borovsky, G.U. Rao, B. Tanyolac, and I. Paran. 2003a. fs3.1: A major fruit shape QTL conserved in Capsicum. Genome 46:1-9.

Ben Chaim, A., Y. Borovsky, W. DeJong, and I. Paran. 2003b. Linkage of the $A$ locus for the presence of anthocyanin and $f_{s} 10.1$ a major fruit shape QTL in pepper. Theor. Appl. Genet. 106:889-894.

Bergh, B.O. and L.F. Lippert. 1964. Six new mutant genes in the pepper, Capsicum annuum L. J. Hered. 55:296-300.

Bergh, B.O. and L.F. Lippert. 1975. Inheritance of axillary shooting in Capsicum. Bot. Gaz. 136:141-145.

Borovsky, Y., M. Oren-Shamir, R. Ovadia, W. deJong, and I. Paran. 2004. The $A$ locus that controls anthocyanin accumulation in pepper encodes a $M Y B$ transcription factor homologous to Anthocyanin2 of Petunia. Theor. Appl. Genet. 109:23-29.

Boswell, V.R. 1937. Improvement and genetics of tomatoes, peppers, and eggplant, p. 176-206. In: Yearbook of agriculture. U.S. Govt. Printing Office, Washington, DC.

Brauer, O. 1962. Untersuchungen ueber Qualitatseigenschaften in F1 Hybriden von Paprika, Capsicum annuum. L. Zeitschrift für Pflanzenzüchtung 48:259-276.

Chalukova, M., S. Daskolov, E. Lukarska, and D. Baralieva. 1993. Beta-orange mutant in pepper (Capsicum annuum L.). Capsicum Eggplant Nwsl. 12:57-58.

Csillery, G. 1980. Gene mapping of the pepper needs more initiatives (contributions to the gene list). Proc. 4th Eucarpia Meeting of Capsicum Working Group,17-19 May 1980, Wageningen, The Netherlands. p. 5-9.

Csillery, G. 1983. New Capsicum mutants found on seedling, growth type, leaf, flower and fruit. Proc. 5th Eucarpia Meeting of Capsicum and Eggplant Working Group, 4-7 July 1983, Plovdiv, Bulgaria. p. 127-130. 
Csillery, G. 1985. Abnormal segregation ratio in a 'lutescens' hybrid in Capsicum baccatum. Capsicum Eggplant Nwsl. 4:43.

Daskalov, S. 1974. Investigations on induced mutants in sweet pepper (Capsicum annuum L.). 1st Meeting of the Capsicum Breeding and Genetics, 1-4 July 1974, Budapest, Hungary. p. 81-90.

Daskalov, S. 1977. Induced mutants in sweet pepper (Capsicum annuum L.). C.R.3-me Congress Eucarpia Piment, AvignonMontfavet, France, p. 155-160.

Daskalov, S., M. Chalukova, D. Baralieva, and E. Lukarska. 1995. Biochemical investigations of an induced beta-orange mutant in sweet pepper (Capsicum annuum L.) and developing varieties with increased beta-carotene content. Proc. 9th Eucarpia Meeting on Genetics and Breeding of Capsicum and Eggplant, 21-25 Aug. 1995, Budapest, Hungary. p. 24-27.

Daskalov, S. and J.M. Poulos. 1994. Updated Capsicum gene list. Capsicum Eggplant Nwsl. 13:15-26.

Deshpande, R.B. 1933. Studies in Indian chilies. 3. The inheritance of some characters in Capsicum annuum L. Indian J. Agr. Sci. 3:219-300. Greenleaf, W.H. 1986. Pepper breeding, p. 67-134. In: Bassett, M.J. (ed.). Breeding vegetable crops. AVI, Westport, CT.

Greenleaf, W.H. and W.H. Hearn. 1976. A round leaf mutant in 'Bigheart' pimiento pepper (Capsicum annuum L.). HortScience 11:463-464.

Gross, J. 1991. Pigments in vegetables: Chlorophylls and carotenoids. AVI, New York, NY.

Hagiwara, T. and Y. Oomura. 1947. On linkage in Capsicum annuum L. Jpn. J. Genet. Suppl. 1:87-96.

Huh, J.H., B.C. Kang, S.H. Nahm, S. Kim, K.S. Ha, M.H. Lee, and B.D. Kim. 2001. A candidate gene approach identifying phytoene synthase as the locus for mature fruit color in red pepper. Theor. Appl. Genet. 102:524-530.

Ikeno, S. 1913. Studien uber dia Bastarde von Paprika. Zeitschrift für Induktive Abstammungs und Vererbungslehre 10:99-144.

Kaiser, S. 1935. The factors governing shape and size in Capsicum fruits: A genetic and developmental analysis. Bul. Torrey Bot. Club 62:433-454.

Khambanonda, I. 1950. Quantitative inheritance of fruit size in red pepper (Capsicum frutescens L.). Genetics 35:322-343.

Kormos, J. and J. Kormos. 1955. A contribution to the genetics of chlorophyll-deficiency. Annales Instituti Biologici (Tihany) 23:177186.

Lightbourn, G.J., R.J. Griesbach, J.A. Novotny, B.A. Clevidence, D.D. Rao, and J.R. Stommel. 2008. Effects of anthocyanin and carotenoid combinations on foliage and immature fruit color of Capsicum annuum L. J. Hered. (in press).

Lippert, L.F., B.O. Bergh, and P.G. Smith. 1965. Gene list for pepper. J. Hered. 56:30-34.

Lippert, L.F., P.G. Smith, and B.O. Bergh. 1966. Cytogenetics of the vegetable crops. Garden pepper, Capsicum. Bot. Rev. 32:24-55.
Ma, Z., S. Yan, X. Luo, X. Shen, X. Wang, Z. Hu, H. Hao, and W. Wei. 2001. Breeding and genetic analysis of yellow-green seedling mutant in pepper. J. Changjiang Veg. 4:31-32.

Mather, K. 1949. Biometrical genetics. 1st Ed. Dover Publ., London, UK.

Matus, Z., J. Deli, and J.J. Szaaboles. 1991. Carotenoid composition of yellow pepper during ripening-isolation of $\beta$-cryptoxanthin 5,6epoxide. J. Agr. Food Chem. 39:1907-1914.

McCamon, K.R. and S. Honma. 1984. Genetics of the 'umbrella' branching habit in Capsicum annuum L. Theor. Appl. Genet. 68:541545 .

Odland, M.L. and A.M. Porter. 1938. Inheritance of the immature fruit color of peppers. Proc. Amer. Soc. Hort. Sci 36:647-651.

Peterson, P.A. 1959. Linkage of fruit shape and color genes in Capsicum. Genetics 44:407-419.

Popovsky, S. and I. Paran. 2000. Molecular analysis of the $Y$ locus in pepper. Theor. Appl. Genet. 101:86-89.

Smith, P.G. 1948. Brown, mature fruit color in pepper (Capsicum frutescens). Science 107:345-346.

Smith, P.G. 1950. Inheritance of brown and green mature fruit colors in pepper. J. Hered. 41:138-140.

Stommel, J.R. and P.W. Bosland. 2006. Pepper, ornamental, Capsicum annuum, p. 561-599. In: Anderson, N.O. (ed.). Flower breeding and genetics: Issues, challenges and opportunities for the 21 st century. Springer, Dordrecht, The Netherlands.

Stommel, J.R. and R.J. Griesbach. 1993. New ornamental Capsicum germplasm: Lines 90C40, 90C44, and 90C53. HortScience 28:858859.

Stommel, J.R. and R.J. Griesbach. 2004. Capsicum annuum L. 'Tangerine Dream'. HortScience 39:448-449.

Stommel, J.R. and R.J. Griesbach. 2005. Capsicum annuum L. 'Black Pearl'. HortScience 40:1571-1573.

Stommel, J.R. and R.J. Griesbach. 2008a. Capsicum annuum L. Lil' Pumpkin $^{\mathrm{TM}}$ and Pepper Jack ${ }^{\mathrm{TM}}$. HortScience (in press).

Stommel, J.R. and R.J. Griesbach. 2008b. Capsicum annuum L. Midnight Creeper ${ }^{\mathrm{TM}}$ and Solar Eclipse ${ }^{\mathrm{TM}}$. HortScience (in press).

Thorup, T.A., B. Tanyolac, K.D. Livingstone, S. Popovsky, I. Paran, and M. Jahn. 2000. Candidate gene analysis of organ pigmentation loci in the Solanaceae. Proc. Natl. Acad. Sci. USA 97:1119211197.

Todorov, J. 1992. Inheritance of the height of red pepper plants for grinding. Proc. 8th Meeting on Genetics and Breeding of Capsicum and Eggplant, 7-10 Sept. 1992, Rome. p. 96-99.

University of Maryland. 2000. Commercial vegetable production recommendations. Univ. Maryland Coop. Ext. Serv. Bul. 236.

Wang, D. and P.W. Bosland. 2006. The genes of Capsicum. HortScience 41:1169-1187.

Warner, J.N. 1952. A method for estimating heritability. Agron. J. $44: 427-443$ 